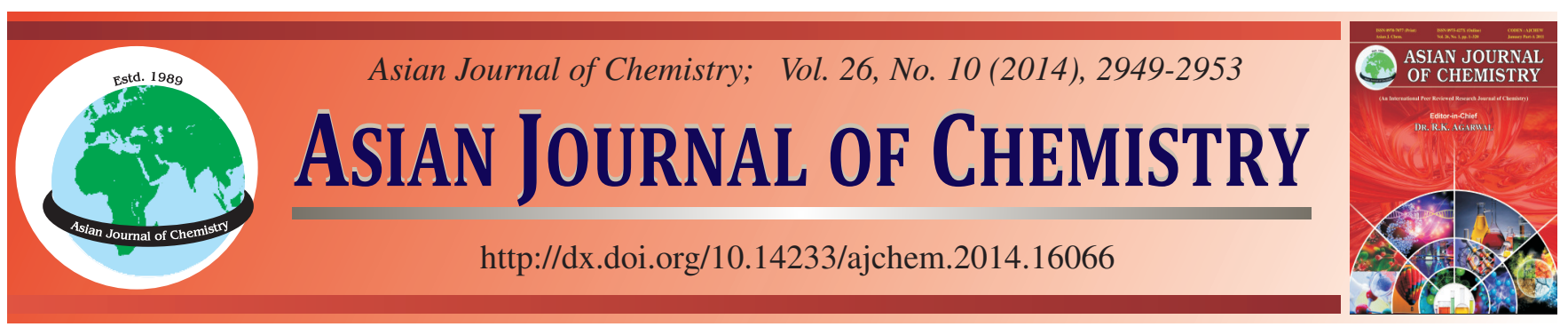

\title{
Synthesis, Characterization and Antibacterial Activity of Organotin(IV) Complexes Derivatives of 2-Chloro-4-nitrobenzoic Acid
}

\author{
Chen-Shang Choong ${ }^{1}$, Yip-Foo Win ${ }^{1, *}$, Sie-Tiong HA ${ }^{1}$ and Emad YousiF ${ }^{2}$
}

${ }^{1}$ Department of Chemical Science, Faculty of Science, Universiti Tunku Abdul Rahman, Perak Campus, Jalan Universiti, Bandar Barat, 31900 Kampar, Perak, Malaysia

${ }^{2}$ Department of Chemistry, College of Science, Al-Nahrain University, Baghdad, Iraq

*Corresponding author: Fax: +60 5 4661676; Tel: +60 5 4688888; E-mail: williamyfw@ yahoo.com

Four organotin(IV) carboxylate complexes have been successfully synthesized and characterized quantitatively and qualitatively. Spectroscopic studies showed that the coordination took place via oxygen atoms from the carboxylate anions. With the exceptional case, spectroscopic studies indicated that one methanol molecule also take part in the coordination to tin(IV) atom moiety in complex 4 resulting the tin(IV) atom exhibited five coordination. From the preliminary in vitro antibacterial screening activity, triphenyltin(IV) (complex 4) showed some significant activity compared to diorganotin(IV) complexes (1-3).

Keywords: Organotin(IV) carboxylate, 2-Chloro-4-nitrobenzoic acid.

\section{INTRODUCTION}

The coordination chemistry of organotin(IV) complexes are extensively studied due to its coordination geometries as well as structural diversity which could expand from simple monomer and dimeric to hexameric, oligomeric and polymeric structures $^{1-6}$. In general, it was also well-documented that the participation of coordinating solvent molecules such as water, acetone and methanol to tin(IV) atoms moieties and its coordination sphere will influence the overall structure of organotin(IV) complexes including its 3D crystal structure packing ${ }^{3,4,6,7}$. Upto-date, numerous studies on organotin(IV) complexes have been carried out in order to study its biological properties against bacterial strains and cancer cell lines to explore its structuralactivity relationship ${ }^{8-15}$.

In this paper, we report on the synthesis and structural characterization of new organotin(IV) carboxylate complexes derived from 2-chloro-4-nitrobenzoic acid, HL as well as the preliminary in vitro antibacterial screening activity of the complexes. All the important results obtained were reported herein.

\section{EXPERIMENTAL}

All the reagents, starting materials as well as the solvents were purchased commercially and used without any further purification. The infrared spectra were recorded using a PerkinElmer System 2000 FTIR Spectrophotometer as a $\mathrm{KBr}$ disc in the frequency range of $4000-400 \mathrm{~cm}^{-1}$. The spectra for ${ }^{1} \mathrm{H},{ }^{13} \mathrm{C}$,
${ }^{1} \mathrm{H}-{ }^{13} \mathrm{C}$ HMQC and ${ }^{119} \mathrm{Sn}$ NMR were recorded on a Joel JNMECX 400 FT-NMR Spectrometer using deuterated $\mathrm{CDCl}_{3}$ and $d_{6}$-DMSO as the solvent and tetramethylsilane, TMS as the internal standard. Elemental C, $\mathrm{H}$ and $\mathrm{N}$ analyses were carried out on a Perkin-Elmer $2400 \mathrm{CHN}$ Elemental Analyzer. The melting points were determined in an open capillary and were uncorrected.

Preparation of dimethyltin(IV) oxide, $\mathrm{Me}_{2} \mathrm{SnO}$ : Dimethyltin(IV) dichloride was dissolved in distilled water and stirred for $16 \mathrm{~h}$. Colourless solution was obtained. Ammonia solution $(60 \%)$ was added into the colourless solution and finally white precipitate was obtained. The precipitate was placed in an oven $\left(60^{\circ} \mathrm{C}\right)$ for a few days to dry.

Preparation of sodium salt: The sodium salt of the acid was obtained by heating under reflux a 1:1 molar mixture of sodium hydroxide, $\mathrm{NaOH}$ and 2-chloro-4-nitrobenzoic acid in ethanol $(50 \mathrm{~mL})$ for $2 \mathrm{~h}$. After a few days, white precipitates were obtained. Sodium salt of 2-chloro-4-nitrobenzoic acid: FTIR as $\mathrm{KBr}$ disc $\left(\mathrm{cm}^{-1}\right)$ selected data: $\mathrm{v}(\mathrm{COO})_{\text {as }} 1617$, $v(\mathrm{COO})_{\mathrm{s}} 1356, \Delta v=262$.

\section{Synthesis of complexes}

Preparation of (2-Cl-4- $\left.\mathrm{NO}_{2}-\mathrm{C}_{6} \mathrm{H}_{3} \mathrm{COO}\right)_{2}\left(\mathrm{CH}_{3}\right)_{2} \mathrm{Sn}$ (1): Complex 1 was obtained by heating under reflux a 1:2 molar mixture of dimethyltin(IV) oxide $(0.33 \mathrm{~g}, 2 \mathrm{mmole})$ and 2chloro-4-nitrobenzoic acid (0.81 g, 4 mmole) in acetonitrile $(50 \mathrm{~mL})$ for $4 \mathrm{~h}$. A clear colourless transparent solution was 
separated by filtration and kept in a bottle. After few days, transparent solids $(0.73 \mathrm{~g}, 66.7 \%$ yield $)$ were collected. m.p.: 180.3-182.9 ${ }^{\circ} \mathrm{C}$. Analysis for $\mathrm{C}_{16} \mathrm{H}_{12} \mathrm{~N}_{2} \mathrm{O}_{8} \mathrm{Cl}_{2} \mathrm{Sn}_{1}: \mathrm{C}, 34.08 ; \mathrm{H}$, $1.93 ; \mathrm{N}, 5.11 \%$. Calculated for $\mathrm{C}_{16} \mathrm{H}_{12} \mathrm{~N}_{2} \mathrm{O}_{8} \mathrm{Cl}_{2} \mathrm{Sn}_{1} \mathrm{C}, 34.95$; $\mathrm{H}, 2.20 ; \mathrm{N}, 5.09 \%$. FTIR ( $\mathrm{KBr}$ disc, $\left.\mathrm{cm}^{-1}\right): \mathrm{v}(\mathrm{C}-\mathrm{H})$ aromatic $3048, v(\mathrm{C}-\mathrm{H})$ saturated 2931; $\mathrm{v}(\mathrm{COO})_{\mathrm{as}} 1717 ; \mathrm{v}(\mathrm{COO})_{\mathrm{s}} 1349$, $\Delta v=368 ; v\left(\mathrm{NO}_{2}\right) 1528, v(\mathrm{O}-\mathrm{Sn}-\mathrm{O}) 624, v(\mathrm{Sn}-\mathrm{C}) 544, \mathrm{v}(\mathrm{Sn}-$ O) 492. ${ }^{1} \mathrm{H}$ NMR (ppm) $\left(\mathrm{CDCl}_{3}\right)$ : $\delta$ : benzene protons $8.16(\mathrm{~d}$, $8.7 \mathrm{~Hz}, 2 \mathrm{H}) ; 8.20$ (dd, $2.3 \mathrm{~Hz}, 6.4 \mathrm{~Hz}, 2 \mathrm{H}) ; 8.36$ (d, $1.8 \mathrm{~Hz}$, $2 \mathrm{H})$; methyl $1.30(\mathrm{~s}, 6 \mathrm{H}), 2 J\left({ }^{119} \mathrm{Sn}-{ }^{1} \mathrm{H}\right)=81.1 \mathrm{~Hz} \cdot{ }^{13} \mathrm{C} \mathrm{NMR}$ (ppm) $\left(\mathrm{CDCl}_{3}\right)$ : $\delta$ : benzene carbons 121.48, 126.30, 133.06, 134.52, 135.71, 149.87; methyl 5.48, COO 170.42. ${ }^{119}$ Sn NMR (ppm) $\left(\mathrm{CDCl}_{3}\right): \delta:-97.20$.

Preparation of (2-Cl-4- $\left.\mathrm{NO}_{2}-\mathrm{C}_{6} \mathrm{H}_{3} \mathrm{COO}\right)_{2}\left(\mathrm{C}_{4} \mathrm{H}_{9}\right)_{2} \mathrm{Sn}$ (2): Complex 2 was obtained by heating under reflux a 1:2 molar mixture of dibutyltin(IV) oxide $(0.50 \mathrm{~g}, 2 \mathrm{mmole})$ and 2chloro-4-nitrobenzoic acid (0.81 g, 4 mmole) in ethanol $(50 \mathrm{~mL})$ for $4 \mathrm{~h}$. A clear colourless transparent solution was separated by filtration and kept in a bottle. After few days, transparent solids $(0.86 \mathrm{~g}, 67.8 \%$ yield) were collected. m.p.: 115.6-116.6 ${ }^{\circ} \mathrm{C}$. Analysis for $\mathrm{C}_{22} \mathrm{H}_{24} \mathrm{~N}_{2} \mathrm{O}_{8} \mathrm{Cl}_{2} \mathrm{Sn}$ : C, 41.98; $\mathrm{H}$, 4.06; N, $4.43 \%$. Calculated for $\mathrm{C}_{22} \mathrm{H}_{24} \mathrm{~N}_{2} \mathrm{O}_{8} \mathrm{Cl}_{2} \mathrm{Sn}_{1}$ : C, 41.67; $\mathrm{H}, 3.82 ; \mathrm{N}, 4.42 \%$. FTIR ( $\mathrm{KBr}$ disc, $\left.\mathrm{cm}^{-1}\right)$ : $\mathrm{v}(\mathrm{C}-\mathrm{H})$ aromatic $3082, v(\mathrm{C}-\mathrm{H})$ saturated $2961,2934,2868 ; \mathrm{v}(\mathrm{COO})_{\text {as }} 1602$; $v(\mathrm{COO})_{\mathrm{s}} 1347, \Delta v=255 ; \mathrm{v}\left(\mathrm{NO}_{2}\right) 1554, v(\mathrm{O}-\mathrm{Sn}-\mathrm{O}) 640, v(\mathrm{Sn}-$ C) $520, \mathrm{v}(\mathrm{Sn}-\mathrm{O}) 485 .{ }^{1} \mathrm{H} \mathrm{NMR}(\mathrm{ppm})\left(\mathrm{CDCl}_{3}\right)$ : $\delta$ : benzene protons $8.13(\mathrm{~d}, 8.3 \mathrm{~Hz}, 2 \mathrm{H}) ; 8.19$ (dd, $1.8 \mathrm{~Hz}, 6.4 \mathrm{~Hz}, 2 \mathrm{H})$; 8.33 (d, $2.3 \mathrm{~Hz}, 2 \mathrm{H})$; butyl, $\mathrm{CH}_{3} 0.95$ (t, $\left.7.4 \mathrm{~Hz}, 6 \mathrm{H}\right), \mathrm{CH}_{2}$ 1.48 (sx, $7.3 \mathrm{~Hz}, 4 \mathrm{H}$ ); $\mathrm{CH}_{2} 1.84$ (qn, 7.3 Hz, 4H); $\mathrm{CH}_{2} 1.98$ (t, $8.7 \mathrm{~Hz}, 4 \mathrm{H}) .{ }^{13} \mathrm{C} \mathrm{NMR}(\mathrm{ppm})\left(\mathrm{CDCl}_{3}\right)$ : $\delta$ : benzene carbons 121.53, 126.09, 132.75, 135.09, 136.02, 149.59; butyl 13.63, 26.41, 26.75, 26.90; COO 173.30. ${ }^{119} \mathrm{Sn}-\mathrm{NMR}(\mathrm{ppm})\left(\mathrm{CDCl}_{3}\right)$ :

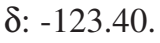

Preparation of $\left[\left\{2-\mathrm{Cl}-4-\mathrm{NO}_{2}-\mathrm{C}_{6} \mathrm{H}_{3} \mathrm{COO}\left(\mathrm{C}_{4} \mathrm{H}_{9}\right)_{2} \mathrm{Sn}\right\}_{2} \mathrm{O}\right]_{2}$ (3): Complex 3 was obtained by heating under reflux a 1:1 molar mixture of dibutyltin(IV) oxide $(0.50 \mathrm{~g}, 2 \mathrm{mmole})$ and 2-chloro-4-nitrobenzoic acid $(0.41 \mathrm{~g}, 2$ mmole $)$. The reaction was carried out in a mixture of ethanol $(60 \mathrm{~mL})$ for $3 \mathrm{~h}$. A clear transparent solution was isolated by filtration and kept in a bottle. After few days, colourless crystals $(0.73 \mathrm{~g}, 83.7 \%$ yield) were collected. m.p.: 175.4-176.5 ${ }^{\circ} \mathrm{C}$. Analysis for $\mathrm{C}_{60} \mathrm{H}_{84} \mathrm{~N}_{4} \mathrm{O}_{18} \mathrm{Cl}_{4} \mathrm{Sn}_{4}: \mathrm{C}, 41.22 ; \mathrm{H}, 4.47 ; \mathrm{N}, 3.20 \%$. Calculated for $\mathrm{C}_{60} \mathrm{H}_{84} \mathrm{~N}_{4} \mathrm{O}_{18} \mathrm{Cl}_{4} \mathrm{Sn}_{4}$ : C, 40.81; H, 4.79; N, $3.17 \%$. FTIR $\left(\mathrm{KBr}\right.$ disc, $\left.\mathrm{cm}^{-1}\right): \mathrm{v}(\mathrm{C}-\mathrm{H})$ aromatic 3100,3065 ; $v(\mathrm{C}-\mathrm{H})$ saturated 2960, 2928, 2861; v $(\mathrm{COO})_{\mathrm{as}} 1594, \mathrm{v}(\mathrm{COO})_{\mathrm{s}} 1342, \Delta \mathrm{v}=$ 252; v $\left(\mathrm{NO}_{2}\right)$ 1530, v(Sn-O-Sn) 624, v(Sn-C) 519, v(Sn-O) 468. ${ }^{1} \mathrm{H}$ NMR (ppm) $\left(\mathrm{CDCl}_{3}\right)$ : $\delta$ : benzene protons $7.72(\mathrm{~d}, 7.8$ $\mathrm{Hz}, 4 \mathrm{H}) ; 8.16$ (d, $8.24 \mathrm{~Hz}, 4 \mathrm{H}) ; 8.29$ (d, $1.8 \mathrm{~Hz}, 4 \mathrm{H})$; butyl, $\mathrm{CH}_{3} 0.86$ (t, $\left.7.4 \mathrm{~Hz}, 12 \mathrm{H}\right), 0.91$ (t, $\left.7.4 \mathrm{~Hz}, 12 \mathrm{H}\right) ; \mathrm{CH}_{2}$ 1.28$1.45(\mathrm{~m}, 16 \mathrm{H}) ; \mathrm{CH}_{2} 1.56-1.78(\mathrm{~m}, 32 \mathrm{H}) .{ }^{13} \mathrm{C}$ NMR $(\mathrm{ppm})$ $\left(\mathrm{CDCl}_{3}\right)$ : $\delta$ : benzene carbons $121.65,125.82,130.28,133.08$, 140.16, 148.65; butyl 13.63, 26.74, 26.79, 27.37, 27.56, 28.75, 30.16; COO 170.62. ${ }^{119} \mathrm{Sn} \mathrm{NMR}(\mathrm{ppm})\left(\mathrm{CDCl}_{3}\right): \delta:-183.76$, -197.49 .

Preparation of 2-Cl-4- $\mathrm{NO}_{2}-\mathrm{C}_{6} \mathrm{H}_{3} \mathrm{COO}\left(\mathrm{C}_{6} \mathrm{H}_{5}\right)_{3} \mathrm{Sn}$.$\mathrm{CH}_{3} \mathrm{OH}$ (4): The title complex was obtained by heating under reflux a 1:1 molar mixture of triphenyltin(IV) hydroxide (0.73 g, 2 mmole) and 2-chloro-4-nitrobenzoic acid (0.41 g, $2 \mathrm{mmol})$ in methanol $(50 \mathrm{~mL})$ for $2 \mathrm{~h}$. A clear transparent solution was isolated by filtration and kept in a bottle. After few days, transparent crystals $(0.71 \mathrm{~g}, 69.5 \%$ yield $)$ were collected. m.p.: $115.6-116.6^{\circ} \mathrm{C}$. Analysis for $\mathrm{C}_{26} \mathrm{H}_{22} \mathrm{~N}_{1} \mathrm{O}_{5} \mathrm{ClSn}$ : C, 53.45; H, 3.74; N, $2.33 \%$. Calculated for $\mathrm{C}_{26} \mathrm{H}_{22} \mathrm{~N}_{1} \mathrm{O}_{5} \mathrm{Cl}_{1} \mathrm{Sn}_{1}$ : $\mathrm{C}, 53.60 ; \mathrm{H}, 3.81 ; \mathrm{N}, 2.40 \%$. FTIR ( $\mathrm{KBr}$ disc, $\left.\mathrm{cm}^{-1}\right)$ : v $(\mathrm{C}-\mathrm{H})$ aromatic 3072, 3052; $\mathrm{v}(\mathrm{C}-\mathrm{H})$ saturated $2979, \mathrm{v}(\mathrm{COO})_{\text {as }} 1618$, $v(\mathrm{COO})_{\mathrm{s}} 1345, \Delta v=273 ; \mathrm{v}\left(\mathrm{NO}_{2}\right) 1522, \mathrm{v}(\mathrm{Sn}-\mathrm{O}) 457 .{ }^{1} \mathrm{H} \mathrm{NMR}$ (ppm) $\left(d_{6} \mathrm{DMSO}\right)$ : $\delta$ : phenyl protons 7.41-7.48 (m, 9H); 7.86$7.88(\mathrm{~m}, 6 \mathrm{H})$; benzene $7.60(\mathrm{~d}, 8.5 \mathrm{~Hz}, 1 \mathrm{H}) ; 8.12(\mathrm{dd}, 2.3 \mathrm{~Hz}$, $6.6 \mathrm{~Hz}, 1 \mathrm{H}) ; 8.19$ (d, $2.3 \mathrm{~Hz}, 1 \mathrm{H}) ; \mathrm{CH}_{3} \mathrm{OH} 3.18$ (d, $4.8 \mathrm{~Hz}$, $3 \mathrm{H}), 4.15$ (q, $5.0 \mathrm{~Hz}, 1 \mathrm{H}) .{ }^{13} \mathrm{C} \mathrm{NMR}(\mathrm{ppm})\left(d_{6}\right.$-DMSO): $\delta$ : phenyl carbons $\mathrm{C}_{\text {ipso }} 142.73(798.0 \mathrm{~Hz}), \mathrm{C}_{\text {ortho }} 136.26$ (45.4 $\mathrm{Hz}), \mathrm{C}_{\text {meta }} 128.44(69.5 \mathrm{~Hz}), \mathrm{C}_{\text {para }} 129.11$; benzene 122.24 , 124.92, 129.44, 130.25, 131.00, 147.67; CH3OH 48.72; COO 167.61. ${ }^{119} \mathrm{Sn}-\mathrm{NMR}$ (ppm) ( $d_{6}$-DMSO): $\delta:-261.65$.

2-Chloro-4-nitrobenzoic acid, HL: The parent acid, 2chloro-4-nitrobenzoic acid, HL was purchased from Acros Organics and used without any further purification. FTIR $(\mathrm{KBr}$ disc, $\left.\mathrm{cm}^{-1}\right)$ : selected data: $\mathrm{v}(\mathrm{OH}) 2823-2577, \mathrm{v}(\mathrm{COO})_{\text {as }} 1708$, $v(\mathrm{COO}){ }_{\mathrm{s}} 1356, \Delta \mathrm{v}=353 .{ }^{1} \mathrm{H}$ NMR $(\mathrm{ppm})\left(d_{6}\right.$-DMSO): $\delta$ : benzene protons $7.98(\mathrm{~d}, 8.7 \mathrm{~Hz}, 1 \mathrm{H}) ; 8.23(\mathrm{dd}, 1.8 \mathrm{~Hz}, 4.1$ $\mathrm{Hz}, 1 \mathrm{H}) ; 8.33$ (d, $2.3 \mathrm{~Hz}, 1 \mathrm{H}) .{ }^{13} \mathrm{C} \mathrm{NMR}$ (ppm) (d $d_{6}$-DMSO): $\delta$ : benzene carbons $122.84,125.82,131.99,132.63,138.11$, 149.42; COO 166.26.

Preliminary in vitro antibacterial screening activity: The synthesized complexes 1-4 and acid, 2-chloro-4-nitrobenzoic acid were screened for their in vitro antibacterial activity against two Gram-negative [Escherichia coli (ATCC 25922) and Pseudomonas aeruginosa (ATCC 27853)] and two Grampositive [Bacillus subtilis (ATCC 38583) and Staphylococcus aureus (ATCC 25923)] bacterial strains by Inhibition Zone Method using paper disc diffusion method ${ }^{16-17}$. The seeded agar (nutrient agar medium) was prepared by cooling the molten agar to $40{ }^{\circ} \mathrm{C}$ and then adding bacterial inoculums containing approximately $1 \times 10^{4}-10^{8}$ colony forming units $(\mathrm{CFU}) / \mathrm{mL}$. The bacterial inoculums were spread on the plate containing agar medium and even coverage was ensured before the agar solidified. The complexes were dissolved in DMSO to prepare $1.0 \mathrm{mg} / \mathrm{mL}$ concentration. Later, small filter paper discs $(6 \mathrm{~mm})$ containing $1.0 \mathrm{mg} / \mathrm{mL}$ of the samples were laid on the growth medium. The plates were incubated immediately at $37^{\circ} \mathrm{C}$ for 20-24 $\mathrm{h}$. The activity was determined by measuring the diameter of the inhibition zone (in $\mathrm{mm}$ ).

\section{RESULTS AND DISCUSSION}

In this study, complexes 1-4 have been obtained in solid state. Complexes 1-4 gave a sharp melting point indicating the isolation of fairly pure complexes. An outline of the proposed structure for complexes 1-4 were depicted in Fig. 1. The micro-elemental analysis for $\mathrm{C}, \mathrm{H}$ and $\mathrm{N}$ data obtained were in agreement with the predicted formula for complexes 1-4. Based on the micro-elemental analysis, it was believed that a methanol molecule was present in complex $\mathbf{4}$ which acted as a solvate molecule in those similar reported comp$\operatorname{lexes}^{3,4,6,7}$. This phenomenon has already been clarified and the X-ray crystal structure of complex $\mathbf{4}$ has been reported ${ }^{4}$.

The $v(\mathrm{O}-\mathrm{H})$ bands of the acid, 2-chloro-4-nitrobenzoic acid was absent in the infrared spectra of salt and complexes 
<smiles>C[Sn](C)(OC(=O)c1ccc([N+](=O)[O-])cc1Cl)OC(=O)c1ccc([N+](=O)[O-])cc1Cl</smiles>

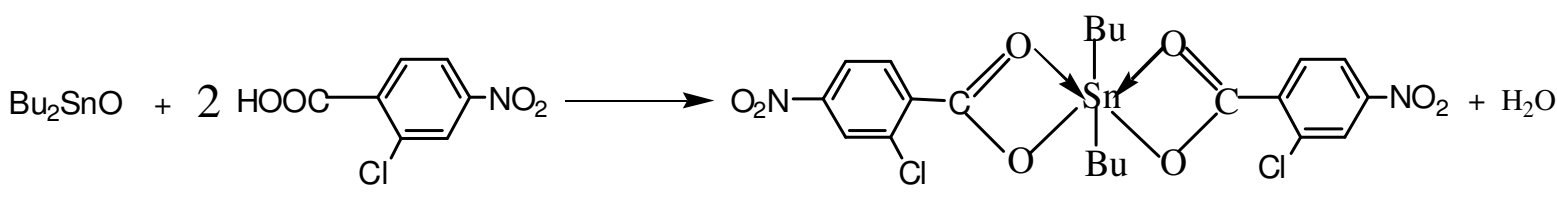

2

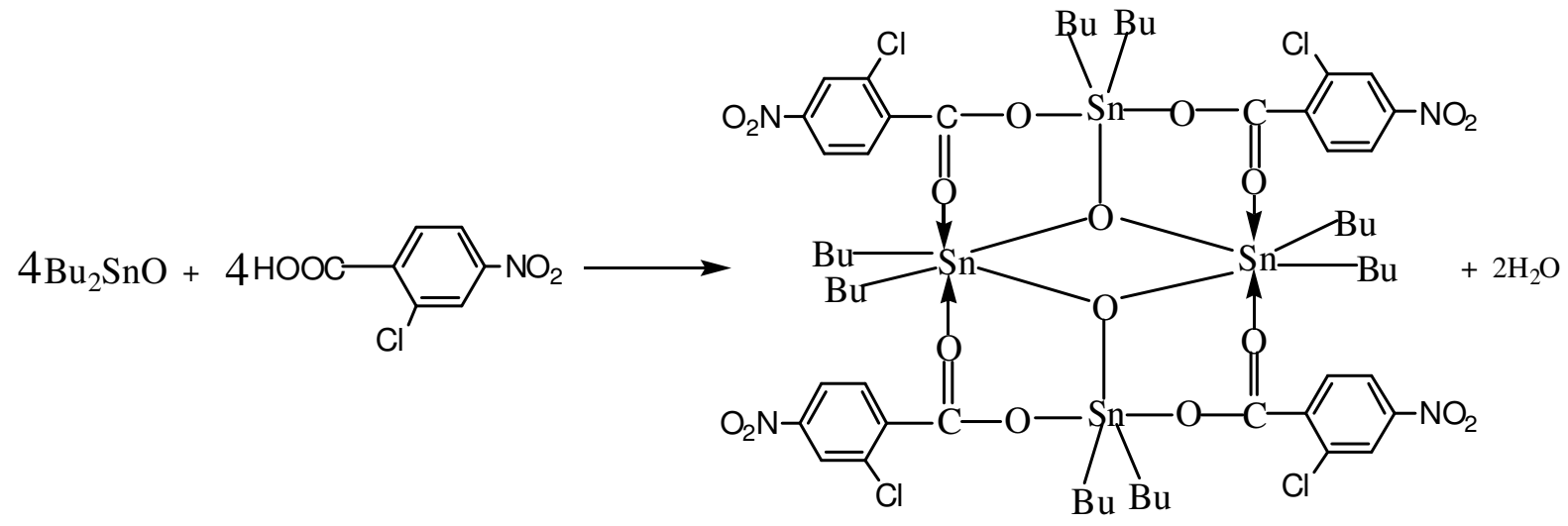

3<smiles>CC[C@H](O)[P@](OC(=O)c1ccc([N+](=O)[O-])cc1Cl)(c1ccccc1)[P+](O)(c1ccccc1)c1ccccc1</smiles>

$\mathrm{Me}=$ methyl, $\mathrm{Bu}=$ butyl $\& \mathrm{Ph}=$ phenyl

Fig. 1. Proposed structure for complexes 1-4

1-4 showed that the deprotonation and coordination of the carboxylate anion. In addition, complexes 1-4 (except complex 1) revealed that the $v(\mathrm{COO})_{\text {as }}$ was shifted to a lower wavelength number compared to the acid, 2-chloro-4-nitrobenzoic acid which signified that the coordination took place via the oxygen atoms of the carboxylate anion. Complex $\mathbf{1}$ was isolated as a monomeric type and its $\Delta v$ was $368 \mathrm{~cm}^{-1}$ which was higher than the sodium salt $\left(\Delta v=262 \mathrm{~cm}^{-1}\right)$ of 2-chloro-4-nitrobenzoic acid, indicating that the carboxylate anions were coordinated to the tin(IV) atom moiety in a monodentate manner and exhibited four coordination number ${ }^{18}$. From the infrared spectra of complexes $\mathbf{2}$ and $\mathbf{3}$, both of the $\Delta v$ values (complex $\mathbf{2}=255$ $\mathrm{cm}^{-1}$, complex $\mathbf{3}=252 \mathrm{~cm}^{-1}$ ) were comparable and lower than the $\Delta v$ of the sodium salt indicating that all the carboxylate anions were bonded to the tin(IV) atoms in a bidentate mode ${ }^{18}$. Hence, as an early structure determination, the tin(IV) atom in complex 2 was six-coordinated and exhibited distorted octahedral geometry. Moreover, since all the carboxylate anions in complex 3 were bonded in bidentate manner, as a result, two tin(IV) atoms exhibited a distorted trigonal bipyramidal geometry and while another two tin(IV) atoms exhibited a distorted octahedral geometry. For complexes derived from
triphenyltin(IV) carboxylate, $\Delta v$ greater than $200 \mathrm{~cm}^{-1}$ would be expected for the monodentate bonding carboxylate anions ${ }^{19}$. Hence, the carboxylate anion in complex 4 would be expected to bond to the tin(IV) atom in monodentate manner since the $\Delta v$ above $200 \mathrm{~cm}^{-1}$. Based on the micro-elemental analysis and crystal structure study, a methanol molecule was present in complex 4. As a result the absorption bands of the aliphatic and aromatic functional groups centered around $3000 \mathrm{~cm}^{-1}$ appeared as though they were sitting on a small hump together with the $v(\mathrm{OH})$ band in the spectra of complexes 4 . Hence, the tin(IV) atom of complex $\mathbf{4}$ was five-coordinated and exhibited a trigonal bipyramidal geometry. For further evidence of the coordination to tin(IV) atom via oxygen atoms was revealed by the presence of the $v(\mathrm{O}-\mathrm{Sn}-\mathrm{O}) / \mathrm{v}(\mathrm{Sn}-\mathrm{O}-\mathrm{Sn})$ and $v(\mathrm{Sn}-\mathrm{O})$ stretching bands which could be found in the wavelength number at $640-624$ and $492-457 \mathrm{~cm}^{-1}$, respectively in the spectra of complexes 1-4.

The ${ }^{1} \mathrm{H}$ NMR spectra of complexes 1-4 exhibited similarities to their acid, 2-chloro-4-nitrobenzoic acid. In the upfield regions of the ${ }^{1} \mathrm{H}$ NMR spectra of the complexes 1-3 showed the signal of the methyl and butyl protons of the organotin(IV) at $1.30 \mathrm{ppm}$ and in the range of 0.86-1.93 ppm, 
respectively. Complex 1 exhibited a sharp singlet in the upfield region with the ${ }^{2} J\left({ }^{119} \mathrm{Sn}-{ }^{1} \mathrm{H}\right)$ value of $81.1 \mathrm{~Hz}$. Based on the Lockhart-Manders equation, the C-Sn-C angles of complex 1 was $132.2^{\circ 20}$. Hence, the tin(IV) atom of complex 1 was not six-coordinated and should be four-coordinated based on the infrared spectroscopy study. For complex 4, the resonances appeared as two well separated sets of multiplets in the regions centering around $\delta=7.44$ and $7.87 \mathrm{ppm}$ (downfield) with the integration values of 9:6, respectively, ascribed to the aromatic protons of the phenyl group ${ }^{21}$. Based on the ${ }^{1} \mathrm{H}$ NMR spectral studies of complex $\mathbf{4}$, the proton resonances originating from the methanol molecule occurred at $\delta=3.18$ and $4.15 \mathrm{ppm}$; based on the integration, only one methanol molecule was present in complex 4.

Evidence of the formation of the complexes was displayed in the ${ }^{13} \mathrm{C}$ NMR spectra. The ${ }^{13} \mathrm{C}$ NMR spectra of complexes 1-4 showed that the $\delta(\mathrm{COO})$ signals shifted to the downfield region which was lower compared to that of the acid, 2-chloro4-nitrobenzoic acid indicating the carboxylate anions were bonded to tin(IV) atoms. Complex 1 exhibited a sharp signal at $5.48 \mathrm{ppm}$ indicating the presence of the methyl groups in the $\mathrm{SnMe}_{2}$ moiety whereas complex 2 exhibited four sharp signals at 13.63, 26.41, 26.75 and $26.90 \mathrm{ppm}$ indicating the presence of the butyl groups of the $\mathrm{SnBu}_{2}$ moiety. Moreover, complex $\mathbf{3}$ was derivatives of organodistannoxane dimer types exhibited two sets of signals corresponding to the butyl groups in the ${ }^{13} \mathrm{C}$ NMR spectra as observed in complex 2 . These two sets of signals were attributed to the butyl groups linked to the exo- and endo-cyclic tin(IV) atoms respectively ${ }^{22}$. Complex 4 revealed the chemical shifts of the $\delta\left({ }^{13} \mathrm{C}\right)_{\text {ipso }}$ at $142.73 \mathrm{ppm}$ indicative of a five-coordinated tin(IV) atom ${ }^{23-25}$. Complex 4 also showed that the ${ }^{1} J\left({ }^{119} \mathrm{Sn}-{ }^{13} \mathrm{C}\right)$ value of $798.0 \mathrm{~Hz}$ lie in the range of $750-850 \mathrm{~Hz}$, thus indicating that the tin(IV) atom in complex 4 was five-coordinated and has a trans-trigonal bipyramid geometry ${ }^{24}$. In addition, in the ${ }^{13} \mathrm{C}$ NMR spectra of complex $\mathbf{4}$, the signals due to the methanol molecule was located at the upfield region at $\delta=48.72 \mathrm{ppm}$. This indicated that the methanol molecule bonded strongly to the tin(IV) atom without any disassociation upon dilution during the preparation of liquid state NMR study.

The $\delta\left({ }^{119} \mathrm{Sn}\right)$ values of the four-coordinated complexes fall in the range between +200 to $-60 \mathrm{ppm}$; the five-coordinated complexes between -90 to $-190 \mathrm{ppm}$ and the six-coordinated complexes between -210 to $-400 \mathrm{ppm}^{26}$. The $\delta\left({ }^{119} \mathrm{Sn}\right)$ values of complexes $\mathbf{1}$ and $\mathbf{2}$ were -97.20 and -123.40 ppm, respectively indicating that the tin(IV) atom in complex 1 remained fourcoordinated whereas the tin(IV) atom in complex $\mathbf{2}$ was fivecoordinated. This may be due to the disassociation of one bidentate bond upon dilution during the preparation of NMR study. Complexes derivatives of organodistannoxane dimer types usually exhibit two well resolved $\delta\left({ }^{119} \mathrm{Sn}\right)$ signals (complex $3=-183.77,-197.49 \mathrm{ppm}$ ). Based on the ${ }^{119} \mathrm{Sn}$ NMR spectra, all the tin(IV) atoms in complex 3 were fivecoordinated and each exhibited a distorted trigonal bipyramidal geometry. This is due to the same phenomenon that happened in complex 2 . Normally, the $\delta\left({ }^{119} \mathrm{Sn}\right)$ value of triphenyltin(IV) complexes lie in the range between -180 to $-260 \mathrm{ppm}$ was believed to be five-coordinated and in the distorted trigonal bipyramid geometry [ $\mathrm{Ph}_{3} \mathrm{SnX} \cdot \mathrm{L}$ ( $\mathrm{L}$ is a monodentate ligand)]. Complex 4 showed that the $\delta\left({ }^{119} \mathrm{Sn}\right)$ value at $-261.66 \mathrm{ppm}$ which lie slightly upfield in the range of -180 to $-260 \mathrm{ppm}$ indicated the tin(IV) atom was five-coordinated and possessed a trans-trigonal bipyramid geometry ${ }^{23-24}$. From the ${ }^{119} \mathrm{Sn}$ NMR study, it is strongly to conclude that the methanol molecule (coordinating solvent) was coordinated to the tin(IV) atom in complex 4 resulting the tin(IV) atom being five-coordinated.

Preliminary in vitro antibacterial screening activity: The preliminary in vitro antibacterial screening activity of acid, 2-chloro-4-nitrobenzoic acid and complexes 1-4 were given in Table-1. Inhibition zones with a diameter less than $10 \mathrm{~mm}$ are considered as weak; larger than $10 \mathrm{~mm}$ but less than 16 $\mathrm{mm}$ are considered as moderate and finally larger than $16 \mathrm{~mm}$ and above are active. Based on the study, acid, HL were found to be inactive and complexes $\mathbf{1 - 3}$ showed a weak to moderate activity to all the tested bacterial strains. In addition, complex 4 was found to show selective activity against Bacillus subtillis and Staphylococcus aureus at $1.0 \mathrm{mg} / \mathrm{mL}$ with the inhibition zones obtained for complex 4 were 23 and $21 \mathrm{~mm}$, respectively indicating that the preliminary in vitro antibacterial activity was in the active mode. Moreover, the inhibition zone diameters of complexes 1-3 in the range of 8-15 mm indicated that their activities were weak to moderate. Hence, the triphenyltin(IV) complexes were more active compared to diorganotin(IV) complexes derivatives against Gram-positive bacterial strains. This phenomenon was due to complex $\mathbf{4}$ was derivatives of triorganotin(IV) which is known to possess higher biological activity compared to diorganotin(IV); the tin(IV) atom moiety of complex 4 was five-coordinated and exists in a trans $-\mathrm{R}_{3} \mathrm{SnO}_{2}$ geometry in solution form hence causing its activity of be greater

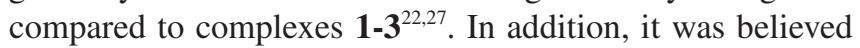

\begin{tabular}{ccccc} 
& \multicolumn{5}{c}{ TABLE-1 } \\
& \multicolumn{1}{c}{$\begin{array}{c}\text { PRELIMINARY in vitro ANTIBACTERIAL SCREENING ACTIVITY OF } \\
\text { 2-CHLORO-4-NITROBENZOIC ACID AND COMPLEXES 1-4 }\end{array}$} \\
\cline { 2 - 5 } Complexes & \multicolumn{4}{c}{ Inhibition Zone (mm) } \\
\cline { 2 - 5 } & Bacillus subtilis & Escherichia coli & Pseudomonas aeruginosa & Staphylococcus aureus \\
\hline 2-Chloro-4-nitrobenzoic acid (HL) & - & - & - & - \\
1 & 10 & 8 & 9 & 8 \\
2 & 15 & 11 & 9 & 11 \\
3 & 15 & 11 & 25 & 12 \\
4 & 23 & 9 & 20 & 21 \\
Chloramphenicol & 27 & 8 & 9 & 19 \\
Doxycycline & 35 & 23 & 25 & 36 \\
Rifampicin & 24 & 16 & 14 & 28 \\
\hline
\end{tabular}

Paper disc diffusion method (in vitro) $=1.0 \mathrm{mg} / \mathrm{mL}$; Reference drug = Chloramphemicol, Doxycycline and Rifampicin 
that the coordinated methanol molecule aided the transportation of active triphenyltin(IV) to the cell or active sites (receptor sites) which enhanced its biological activity ${ }^{28-30}$. Although complex 4 showed significant in vitro antibacterial activity against Gram-positive bacterial strains but the value obtained were lower compared to the reference drugs.

\section{Conclusion}

Complexes 1-4 have been successfully synthesized. The structural as well as the coordination number of tin(IV) atoms moieties of complexes 1-4 have been successfully characterized quantitatively and qualitatively. Based on the preliminary in vitro antibacterial screening activity, complex 4 [triphenyltin(IV)] showed better activity compared to complexes $\mathbf{1 - 3}$ [diorganotin(IV)] against Gram-positive bacterial strains but lower activity compared to the reference drugs.

\section{ACKNOWLEDGEMENTS}

The authors would like to thank Universiti Tunku Abdul Rahman (UTAR) for the UTAR Research Fund (Project No. IPSR/RMC/UTARRF/C1-11/C07) for financial support as well as technical assistance and facilities.

\section{REFERENCES}

1. R. Zhang, J. Sun and C. Ma, J. Organomet. Chem., 690, 4366 (2005).

2. Y.F. Win, S.G. Teoh, J.B.-J. Teh, H.K. Fun and L. Zakaria, Acta Crystallogr., E63, m323 (2007).

3. Y.F. Win, S.G. Teoh, M.R. Vikneswaran, J.H. Goh and H.K. Fun, Acta Crystallogr., E66, m695 (2010).

4. Y.-F. Win, C.-S. Choong, S.-T. Ha, C.K. Quah and H.K. Fun, Acta Crystallogr., E67, m535 (2011).

5. M.M. Amini, A. Azadmehr, V. Alijani, H.R. Khavasi, T. Hajiashrafi and A.N. Kharat, Inorg. Chim. Acta, 362, 355 (2009).

6. F.W. Yip, S.G. Teoh, B.M. Yamin and S.W. Ng, Acta Crystallogr., E66, m1164 (2010).

7. X. Xiao, D. Du, X. Han, J. Liang, M. Tian, D. Zhu and L. Xu, J. Organomet. Chem., 713, 143 (2012).

8. K.C. Molloy, T.G. Purcell, K. Quill and I.W. Nowell, J. Organomet. Chem., 267, 237 (1984).
9. R. Willem, A. Bouhdid, B. Mahieu, L. Ghys, M. Biesemans, E.R.T. Tiekink, D. de Vos and M. Gielen, J. Organomet. Chem., 531, 151 (1997).

10. S.G. Teoh, S.H. Ang, S.B. Teo, H.K. Fun, K.L. Khew and C.W. Ong, J. Chem. Soc., Dalton Trans., 465 (1997).

11. F. Novelli, M. Recine, F. Sparatore and C. Juliano, IL Farmaco, 54, 237 (1999).

12. M. Gielen, M. Biesemans, D. de Vos and R. Willem, J. Inorg. Biochem., 79, 139 (2000).

13. K.A. Crouse, K.-B. Chew, M.T.H. Tarafder, A. Kasbollah, A.M. Ali, B.M. Yamin and H.K. Fun, Polyhedron, 23, 161 (2004).

14. S. Jabbar, I. Shahzadi, R. Rehman, H. Iqbal, Qurat-Ul-Ain, A. Jamil, R. Kousar, S. Ali, S. Shahzadi, M.A. Choudhary, M. Shahid, Q.M. Khan, S.K. Sharma and K. Qanungo, J. Coord. Chem., 65, 572 (2012).

15. F.T. Vieira, G.M. de Lima, J.R.S. Maia, N.L. Speziali, J.D. Ardisson, L. Rodrigues, A. Correa and O.B. Romero, Eur. J. Med. Chem., 45, 883 (2010)

16. A.W. Bauer, W.M.M. Kirby, J.C. Sherris and M. Turck, Am. J. Clin. Pathol., 45, 493 (1966).

17. O.D. Dhingra and J.B. Sinclair, Basic Plant Pathology Methods, CRC Press, United State, edn 4, p. 245 (1987).

18. G.K. Sandhu and S.P. Verma, Polyhedron, 6, 587 (1987).

19. L.L. Yeap and S.G. Teoh, J. Coord. Chem., 56, 701 (2003).

20. A. Fumagalli, S. Martinengo, G. Ciani and G. Marturano, J. Inorg. Chem., 25, 592 (1986).

21. A. Sau and R.R. Holmes, J. Organomet. Chem., 217, 157 (1981).

22. M. Danish, H.G. Alt, A. Badshah, S. Ali, M. Mazhar and Nazar-ulIslam, J. Organomet. Chem., 486, 51 (1995).

23. J. Holecek, K. Handlír, M. Nádvornik and A. Lycka, J. Organomet. Chem., 258, 147 (1983).

24. J. Holecek, M. Nadvorník, K. Handlír and A. Lycka, J. Organomet. Chem., 241, 177 (1983).

25. T.S. Basu Baul, S. Dhar, S.M. Pyke, E.R.T. Tiekink, E. Rivarola, R. Butcher and F.E. Smith, J. Organomet. Chem., 633, 7 (2001).

26. J. Holecek, M. Nádvornik, K. Handlir and A. Lycka, J. Organomet. Chem., 315, 299 (1986).

27. T.S. Basu Baul, S. Dutta, E. Rivarola, R. Butcher and F.E. Smith, J. Organomet. Chem., 654, 100 (2002).

28. C. Pettinari, F. Marchetti, A. Cingolani, D. Leonesi, E. Mundorff, M. Rossi and F. Caruso, J. Organomet. Chem., 557, 187 (1998).

29. M. Nath, R. Yadar, G. Eng, T.-T. Nguyen and A. Kumar, J. Organomet. Chem., 577, 1 (1999).

30. M. Nath, R. Jairath, G. Eng, X. Song and A. Kumar, Spectrochim. Acta A, 62, 1179 (2005). 